Медведєва A.O., к. т. н, дои.

Київський національний торговельно-економічний університет, м. Київ, Україна Google Scholar https://scholar.google.com.ua/citations?user=1ibXuf4AAAAJ\&hl=ru

\title{
БЕЗГЛЮТЕНОВЕ ПЕЧИВО ПІСОЧНЕ 3 КУКУРУДЗЯНИМ ТА РИСОВИМ БОРОШНОМ
}

За останні 10 років діагностування аутоімунного захворювання травної системи - целіакії збільшилось серед населення майже втричі. Ця хвороба характеризується ураженням слизової оболонки тонкої кишки у генетично схильних осіб під впливом білків зерна злакових культур пшениці, жита, ячменю, вівса. Білки цих злакових мають свої назви (гліадин і глютенін), але їх прийнято об'єднувати загальним терміном «глютен».

У харчовій промисловості глютен відомий як клейковина, від вмісту і властивостей якої залежить якість випеченого виробу, його аромат, консистенція, пишність тощо. Проте, глютен може завдавати шкоди шлунково-кишковому тракту людини.

Мета дослідження: наукове обгрунтування та розроблення технології безглютенового печива пісочного з використанням кукурудзяного та рисового борошна.

Об'єкт дослідження: технологія безглютенового печива з кукурудзяно-рисовим борошном.

Предмет дослідження: печиво пісочне з пшеничним борошном, печиво пісочне з рисовим і кукурудзяним борошном, пшеничне, рисове та кукурудзяне борошно.

За допомогою постановочних дослідів замінили пшеничне борошно на кукурудзяне та рисове. А також замінили цукор, додавши до складу печива фініки та родзинки; збагатили смак і аромат печива за допомогою цедри лимону та апельсину, поверхню посипали кунжутом.

Розроблене печиво пісочне безглютенове має приємний смак, 3 присмаком апельсину та лимону; запах - властивий кукурудзяному і рисовому борошну з нотками кунжуту; консистенцію - розсипчасту.

Розраховано хімічний склад безглютенового печива пісочного. Кількість вітамінів групи В збільшилась: $\mathrm{B}_{1}$ - на 20\%; $\mathrm{B}_{2}$ - на 10\%; $\mathrm{B}_{5}-31 \%$. Збільшився вміст мінеральних речовин, особливо кальцію у 3 рази. Кальцій разом з білком становить основу кісткової тканини 
та зубів. Недоотримання необхідної кількості кальцію тягне за собою проблеми зі здоров'ям. Щоденне надходження в організм кальцію в кількості від 500 до 1000 мг дозволить зберегти обов'язкову норму кальцію. Магній - це саме той елемент, який необхідний для нормального обміну речовин, входить до складу практично всіх тканин i важливий для функціонування клітин організму. Завдяки йому відбувається передача нервових імпульсів, скорочуються м'язи, краще засвоюється кальцій.

На основі отриманих вище даних побудовано модель якості безглютенового печива з кукурудзяно - рисовим борошном (рис. 1).

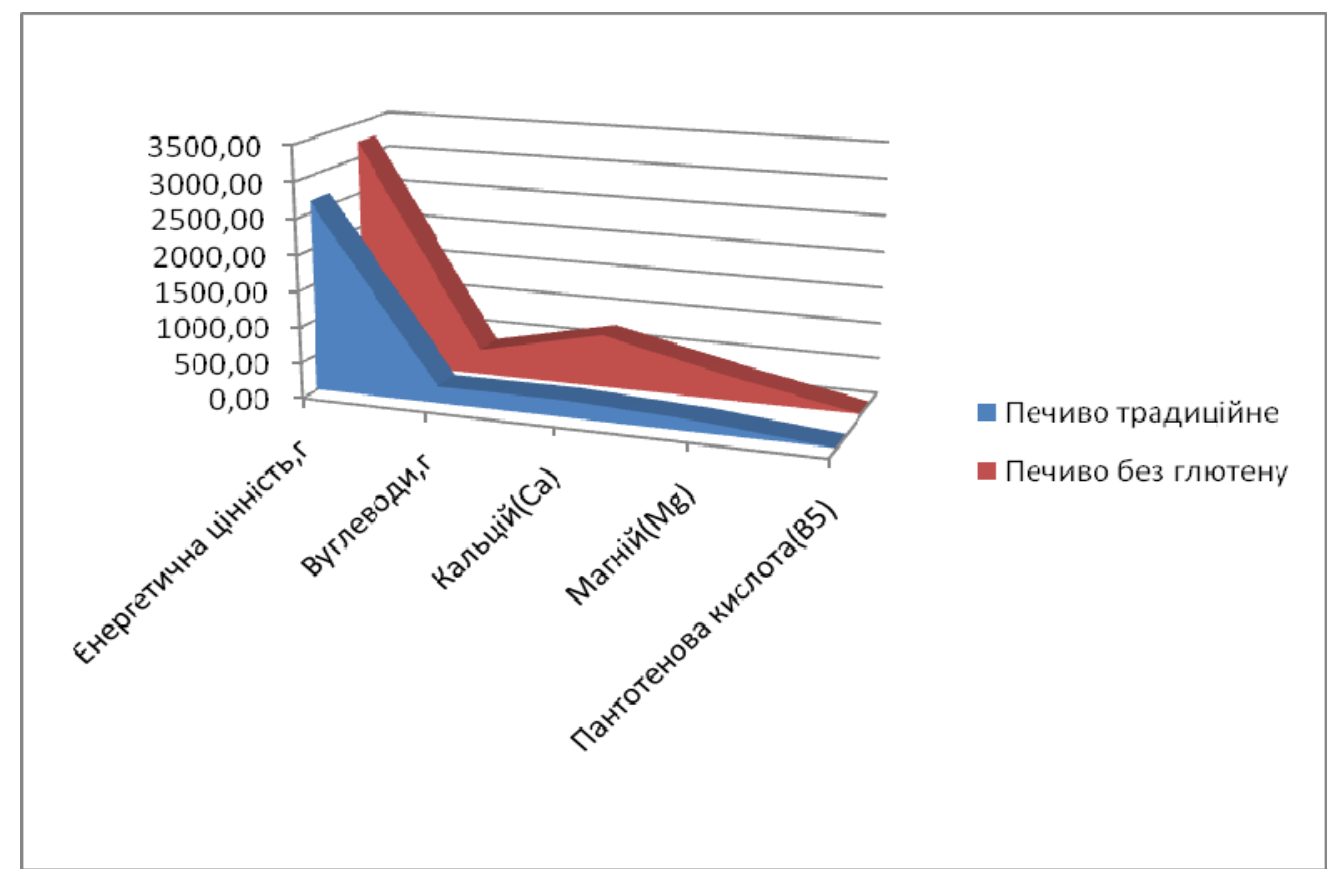

Рис. 1. Модель якості «Печива пісочного без глютену»

Резюмуючи вищезазначене, можна зробити висновок, що розроблене безглютенове печиво пісочне з кукурудзяним та рисовим борошном має високу органолептичну оцінку, підвищений вміст мінеральних речовин, вітамінів порівняно з виробами традиційного приготування. Отже, його рекомендується вживати хворим на целіакію, а також іншим верствам населення.

\section{Список бібліографічних посилань}

1. Збірник рецептур страв і кулінарних виробів 3 використанням біологічно активних добавок. Київ : Книга, 2004. 428 с.

2. Скурихин И.М. Химический состав пищевых продуктов / М. Скурихин. M., 2002. C. 235.

3. Здобнов А.И. Сборник рецептур блюд и кулинарных изделий: Для предприятий общественного питания / А.И. Здобнов. Київ, 2010. $680 \mathrm{c}$. 